\title{
山口県における難聴乳幼児の療育体制に関わる 問題点の検討
}

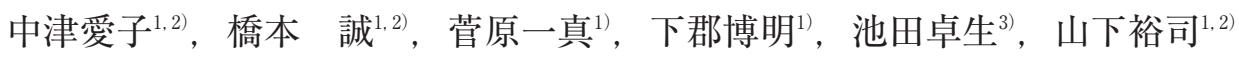 \\ ${ }^{11}$ 山口大学大学院医学系研究科耳鼻咽喉科学分野 \\ ${ }^{2}$ 山口口大学医学部附属病院高次統合感覚器医療センター \\ ${ }^{3}$ 鼓ヶ浦こども医療福祉センター耳鼻咽喉科
}

\begin{abstract}
要旨：0歳で発見された難聴児の療育状況を調査し, 山口県における難聴乳幼児の療育が 早期から充実して行われるための課題について検討した。対象は1998年 6 月から 2012 年12 月までに, 山口大学医学部附属病院耳鼻咽喉科を聴力精查, または療育目的に初回受診 し, 難聴発見年齢が 0 歳で, 療育歴を把握することができた 25 例を対象とした。 0 歳から 3 歳までの療育状況を調査した結果，重複障害のない児では12名，重複障害のある児では 2 名が， 2 歳または 3 歳までに医療機関と特別支援学校教育相談の 2 か所で指導を受けて いた。しかし，他の11例は特別支援学校教育相談に通っていなかった。また，重複障害児 は当科受診の回数が少なく, 児が通っている障害児施設との連携も行われていなかった。 今後, 山口県の難聴乳幼児の療育には身近な地域で難聴児を受け入れる体制の充実, 家庭 訪問による指導，重複障害児の通う障害児施設との連携が必要と考えられる。
\end{abstract}

$$
\text { ーキーワードー }
$$

難聴乳幼児，療育体制，早期の療育

\section{はじめに}

山口県では, 2003年10月に新生児聴覚検查事業が 開始された ${ }^{1,2)}$ 。新生览聴覚検查の実施率は, 開始か ら $5 \sim 6$ 年の間, $60 \%$ 台であった ${ }^{3}$ 。その当時は, 1 歳 6 か月览健診や 3 歳児健診, 親の気づきや小览科 医の指摘が難聴発見の主な契機であり, 難聴発見が 遅れていだ)。しかし，その後，年々上昇し， 2012 年度には $96 \%$ に達した ${ }^{3)}$ 。新生児聴覚検査後の精密 検查実施医療機関は県内に 5 か所ある ${ }^{1,3)}$ が, その うちの 3 か所では, 補聴器適合や聴能・言語指導も 実施している ${ }^{3)}$ 。また，教育機関では，2校の特別 支援学校が教育相談の形で難聴児を 0 歳から受け入 れている3)。山口県には難聴幼児通園施設のような 難聴児に特化した施設はないが，2007年度，県の東 部にある知的障害児通園施設（現在：児童発達支援
センター）が難聴児のクラスを設置した。現在は周 辺地域の難聴児を受け入れ, 療育を行っている。 山口県には中心的な大都市がなく, 都市が分散し ているという特徵がある。そのため, 難聴児を 1 か 所に集めて指導するのではなく，児の身近な地域で 指導が受けられるよう, 上記のように医療, 教育, 福祉の各領域から支援する体制を整えてきた。しか し, 一人の子どもに対する指導の回数は, 表 1 に示 す通り，施設ごとに異なっている。医療機関では， 指導は週 1 回程度であるが, 特別支援学校の教育相 談と児童発達支援センターに設置された難聴児のク ラスでは, 個別指導と集団指導を週に 1 回ずつ実施 している。当科では, 受け入れ人数の関係で一人の 子どもに対する指導回数に制限があるため, 指導の 場を拡大することを目的に, 特別支援学校と連携し て療育を行うことを基本としている。 
表 1 施設ごとの指導回数

\begin{tabular}{|c|c|c|}
\hline 医療機関 & \multicolumn{2}{|c|}{ 年齢問わず, 週 1 回程度 } \\
\hline 特別支援学校 & $\begin{array}{l}0 \text { 歳児 } \\
1 \text { 歳児 } \\
2 \text { 歳児 } \\
\text { 幼稚部 }\end{array}$ & $\begin{array}{l}\text { 週 } 1 \text { 回（個別）} \\
\text { 週 } 2 \text { 回（個別 } 1 \text { 回·集団 } 1 \text { 回 }) \\
\text { 週 } 2 \text { 回（個別 } 1 \text { 回·集団 } 1 \text { 回 }) \\
\text { 毎日 }\end{array}$ \\
\hline $\begin{array}{l}\text { 県東部の児童発達支援センターに } \\
\text { 設置された難聴児のクラス }\end{array}$ & 0 歳〜就学まで & 週 2 回（個別 1 回 · 集団 1 回） \\
\hline
\end{tabular}

就学後は, 特別支援学校と小学校の難聴特別支援 学級が中心となり, 児のきこえや使用するコミュニ ケーション手段に応じた教育的支援を行っている。 山口県は難聴特別支援学級を設置した小学校が 27 校 （2013年 4 月時点）と多く, 地域の学校で難聴児を 受け入れる体制が整備されてきた。これに比べる と, 就学前の難聴児を指導する施設は限られている と考えられる。したがって, 難聴が早期に発見され ても, 身近な地域で十分に療育が受けられる状況に あるとは言い難い。そこで, 本研究では，0歳で発 見された難聴児の療育状況を調査し，その問題点を 明らかにし, 山口県における難聴乳幼児の療育が早 期から充実して行われるための課題について検討し た。

\section{対象および方法}

1998年 6 月から 2012年12月までに, 山口大学医学 部附属病院耳鼻咽喉科を聴力精査，または療育目的 に初回受診した児のうち, 難聴発見年齢が 0 歳, か つ，乳幼児期の療育歴を把握することができた 25 例 （男児15例，女児10例）を対象とした。この25例に 対し, 診療録をもとに, 難聴発見の契機，精查開始 月齢, 補聴器装用開始月齢, 聴覚検查の経過, 療育 経過を調査した。今回は早期の療育の実態を調査す ることに主眼を置き， 0 歳から 3 歳までを早期とし て, その時期に補聴器や人工内耳の装用指導, 聴能 · 言語指導など, 難聴児の発達に必要な指導をどこで 受けたかを調べた。また, 3 歳以降, 就学前まで は, 集団保育が中心となる年齢のため, その時期に ついては，児の主たる集団保育の場を調べた。

聴力は, 良聴耳の 4 分法の平均聴力レベルをもと に $25 \mathrm{dBHL}$ 以上 $40 \mathrm{dBHL}$ 未満を軽度難聴，40dBHL 以上 $70 \mathrm{dBHL}$ 未満を中等度難聴, $70 \mathrm{dBHL}$ 以上 90
dBHL 未満を高度難聴, 90dBHL 以上を重度難聴と した。純音聴力検查が実施できない児には, 聴性行 動反応聴力検查（BOA）, または条件詮索反応聴力 検査 $(\mathrm{COR})$ の $500 \mathrm{~Hz}, 1000 \mathrm{~Hz}, 2000 \mathrm{~Hz}, 4000 \mathrm{~Hz}$ の閾值の平均と聴性脳幹反応聴力検査 (ABR) の結 果を総合し, 聴力の評価を行った。難聴確定時の聴 力は, 重度難聴が 12 名, 高度難聴が 6 名, 中等度難 聴が 7 名であった。また, 症例の背景として, 難聴 以外の障害を併せ持つ重複障害児を 8 名認めた。

\section{結果}

\section{1. 難聴発見の契機}

表 2 に難聴発見の契機を示した。当科では，当院 の Neonatal Intensive Care Unit (NICU) や小児科 と連携し, 難聴ハイリスク児に対する聴覚検査を行 っている。これは，新生児聴覚スクリーニングとは 検査の流れが異なるものである。そのため, 新生児 聴覚スクリーニングとリスク児に対する聴覚検查は 分けて記載した。

山口県新生児聴覚検査事業が開始される前に出生 した児の難聴発見の契機は, 1名が新生児聴覚スク リーニング， 5 名が難聴ハイリスク児に対する聴覚 検查， 2 名が小児科医による難聴の指摘， 2 名が親 の気づきであった。山口県新生児聴覚検查事業が開 始された後に出生した児の難聴発見の契機は, 10名 が新生児聴覚スクリーニング，5名が難聴ハイリス ク児に対する聴覚検査であった。小児科医による難 聴の指摘や親の気づきがきっかけで発見された症例 はなかった。また，対象児に新生児聴覚スクリーニ ングを pass した児もいなかった。

2. 精查開始月齢・補聴器装用開始月齢 - 人工内耳 手術時年齢

表 3 に精査開始月齢と補聴器装用開始月齢，人工 
表 2 難聴発見の契機

\begin{tabular}{|c|c|c|c|c|c|c|}
\hline \multirow{2}{*}{ 発見の契機 } & \multicolumn{2}{|c|}{ 重度難聴（n=12） } & \multicolumn{2}{|c|}{ 高度難聴 $(\mathrm{n}=6)$} & \multicolumn{2}{|c|}{ 中等度難聴 $(\mathrm{n}=7)$} \\
\hline & 事業開始前 & 事業開始後 & 事業開始前 & 事業開始後 & 事業開始前 & 事業開始後 \\
\hline 新生児聴覚スクリーニング & 1名 & 5 名 & & 2 名 & & 3 名 \\
\hline リスク児に対する聴覚検査 & 1名 & 2 名 & 3 名 & 1 名 & 1 名 & 2 名 \\
\hline 小児科医による難聴の指摘 & 1名 & & & & 1 名 & \\
\hline & ( 0 歳 6 か月) & & & & ( 0 歳11か月) & \\
\hline 親の気づき & 2 名 & & & & & \\
\hline & (1名：0歳 8 只) & & & & & \\
\hline & (1名：0歳10か月) & & & & & \\
\hline
\end{tabular}

注）事業開始前：山口県新生児聴覚検査事業が開始される前に出生した児

注）事業開始後：山口県新生児聴覚検査事業が開始された後に出生した児

注）リスク児に対する聴覚検査は，難聴のリスクファクターを持つ児に対し， Neonatal Intensive Care Unit (NICU) や 小児科と連携して行っているものである。

表 3 精查開始月齢・補聴器装用開始月齢・人工内耳手術時年齢

\begin{tabular}{|c|c|c|c|c|c|c|c|c|c|c|}
\hline \multirow[b]{2}{*}{ 発見の契機 } & \multicolumn{4}{|c|}{ 重度難聴（n=12） } & \multicolumn{3}{|c|}{ 高度難聴（n=6） } & \multicolumn{3}{|c|}{ 中等度難聴（n=7） } \\
\hline & 症例 & $\begin{array}{c}\text { 精査開始 } \\
\text { 月歯令 }\end{array}$ & $\begin{array}{c}\text { 補聴器装用 } \\
\text { 開始月齢 }\end{array}$ & $\begin{array}{l}\text { 人工内耳 } \\
\text { 手術時年齢 }\end{array}$ & 症例 & $\begin{array}{c}\text { 精査開始 } \\
\text { 月齢 }\end{array}$ & $\begin{array}{l}\text { 補聴器装用 } \\
\text { 開始月齢 }\end{array}$ & 症例 & $\begin{array}{c}\text { 精査開始 } \\
\text { 月齢 }\end{array}$ & $\begin{array}{c}\text { 補聴器装用 } \\
\text { 開始月歯令 }\end{array}$ \\
\hline \multirow{6}{*}{$\begin{array}{l}\text { 新生児聴覚スクリ } \\
\text { ーニング }(\mathrm{n}=11)\end{array}$} & 1 & 0 か月 & 4 か月 & 1 歳 6 か月 & 7 & 2 か月 & 6 か月 & 9 & 1 か月 & 7 か月 \\
\hline & 2 & 1 か月 & 5 か月 & 1 歳 6 か月 & 8 & 4 か月 & 6 か月 & 10 & 1 か月 & 7 か月 \\
\hline & 3 & 2 か月 & 5 か月 & 5 歳 2 か月 & & & & 11 & 1 か月 & 7 か月 \\
\hline & 4 & 2 か月 & 5 か月 & & & & & & & \\
\hline & 5 & 0 か月 & 6 か月 & 2 歳10か月 & & & & & & \\
\hline & 6 & 6 か月 & 22か月 & & & & & & & \\
\hline \multirow{4}{*}{$\begin{array}{l}\text { リスク児に対する } \\
\text { 聴覚検査 }(n=10)\end{array}$} & 12 & 3 か月 & 4 か月 & & 15 & 1 か月 & 6 か月 & 19 & 1 か月 & 7 か月 \\
\hline & 13 & 3 か月 & 6 か月 & & 16 & 2 か月 & 7 か月 & 20 & 7 か月 & 11か月 \\
\hline & 14 & 3 か月 & 6 か月 & & 17 & 4 か月 & 7 か月 & 21 & 5 か月 & 25か月 \\
\hline & & & & & 18 & 6 か月 & 8か月 & & & \\
\hline $\begin{array}{l}\text { 小児科医による難 } \\
\text { 聴の指摘 }(\mathrm{n}=2)\end{array}$ & 22 & 6 か月 & 8 か月 & & & & & 23 & 11か月 & 14か月 \\
\hline \multirow{2}{*}{ 親の気づき $(\mathrm{n}=2)$} & 24 & 8 か月 & 8 か月 & 4 歳 4 か月 & & & & & & \\
\hline & 25 & 11か月 & 11か月 & 4 歳 7 か月 & & & & & & \\
\hline
\end{tabular}

注）リスク児に対する聴覚検査について, Neonatal Intensive Care Unit（NICU）に入室していた症例13，14，16，17，20，21 は，全身状態が落ち着いてから検査を実施した。

注）症例18は，生後 5 か月で髄膜炎に罹患した症例である。

注）症例 3 , 症例 25 は, 4 歳の時に難聴が進行したため, 人工内耳埋め込み術に至った症例である。

内耳手術時年齢を記した。新生览聴覚スクリーニン グを受けた児では, 症例 6 の精査開始が 6 か月と遅 れていた。リスク児に対する聴覚検査を受けた児で は, 症例13, 14, 16, 17, 20, 21が Neonatal Intensive
Care Unit（NICU）に入室していたため，検査は全 身状態が落ち着いてから実施した。このうち, 症例 16，17は，聴覚検査の経過から進行性難聴と診断さ れ，補聴器の装用が必要と判定された症例であっ 
た。また，症例18は髄膜炎後に難聴を疑われ，聴覚 検査を受けた児であった。小児科医による難聴の指 摘，および親の気づきが発見の契機であった児で は，精査開始の遅れは認められなかった。

補聴器装用開始月齢は25例中 22 例が 0 歳であっ た。次に，1歳以降に装用を開始した 3 例の経緯を 述べる。症例 6 は, 新生児聴覚検査を受けた後, 生 後 6 か月まで精查機関を訪れず，その後も受診が途 絶えがちで, 補聴器の装用を開始したのは22か月 （1歳10か月）であった。症例21は, 乳児期に診断 され補聴器の試聴を開始したが, 経済的な理由で補 聴器を購入するまでに期間を要し，本格的に装用を 開始したのは25か月（2歳 1 か月）であった。症例 23は，生後11か月で精查を開始したため，難聴の診 断と補聴器の装用開始が 1 歳過ぎになった。

重度難聴児のうち, 当科で人工内耳埋め込み術を
受けた症例は 6 例であった。症例 3 は 5 歳 2 か月, 症例 25 は 4 歳 7 か月と, 手術時の年齢が高いが，こ の 2 名は聴覚検査の経過から難聴の進行が認められ たため, 人工内耳の適応が検討された症例であっ た。

3。療育の実態

1 ）重複する障害のない症例

難聴のほかに重複する障害のない17例の療育状況 を表 4 に示した。 0 歳から 3 歳までに難聴に関わる 指導を受けた機関は，0歳では15名が医療機関 1 か 所， 1 名（症例 5 ）が医療機関と特別支援学校教育 相談の 2 か所であった。しかし，医療機関と特別支 援学校の教育相談で指導を受ける览は年齢とともに 増加し, 1 歳で 6 名, 2 歳で12名に上った。一方, 特別支援学校には通わず，ことばの教室で指導を受

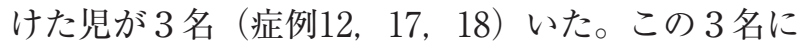

表4 重複障害のない17例の療育状沉

: 当科 $\bigcirc$ : 他院耳鼻科

: 特別支援学校 教育相談 $\square$ : ことばの教室

\begin{tabular}{|c|c|c|c|c|c|c|c|}
\hline \multirow{2}{*}{ 症例 } & \multirow{2}{*}{ 難聴の程度 } & \multicolumn{4}{|c|}{ 難聴に関わる指導を受けた施設 } & \multirow{2}{*}{$\begin{array}{c}\text { 歳以降の } \\
\text { 主たる集団保育の場 }\end{array}$} & \multirow{2}{*}{ 備考 } \\
\hline & & 0 歳 & 1 歳 & 2 歳 & 3 歳 & & \\
\hline 1 & \multirow{11}{*}{ 重度 } & $\bigcirc$ & $\bigcirc$ & ○० & ○๐ & 特別支援学校幼稚部 & \\
\hline 2 & & O & O & O & O & 地元の幼稚園 & 保護者の就労 \\
\hline 3 & & O & O & Oت & On & 地元の保育所 & \\
\hline 5 & & $\bigcirc$ & $\bigcirc$ & O■O & $\bigcirc \square$ & 地元の保育所 & \\
\hline 6 & & - & O & On & On & 特別支援学校幼稚部 & \\
\hline 12 & & O & O & O & $\square$ & 地元の幼稚園 & 自宅が遠方 \\
\hline 13 & & 0 & 0 & On & On & 特別支援学校幼稚部 & \\
\hline 14 & & 0 & 0 & On & On & 特別支援学校幼稚部 & \\
\hline 22 & & 0 & On & Ot & On & 特別支援学校幼稚部 & \\
\hline 24 & & 0 & On & Ot & On & 特別支援学校幼稚部 & \\
\hline 25 & & 0 & On & Ot & On & 特別支援学校幼稚部 & \\
\hline 7 & \multirow{6}{*}{ 高度 } & 0 & Oᄆ & Oت & - & - & \\
\hline 8 & & 0 & On & Ot & - & - & \\
\hline 15 & & 0 & 0 & 0 & 0 & 地元の幼稚園 & 母が次子を出産 \\
\hline 16 & & 0 & 0 & On & On & 特別支援学校幼稚部 & \\
\hline 17 & & 0 & 0 & O & $\square$ & 地元の小規模保育施設 & 自宅が遠方 \\
\hline 18 & & 0 & 0 & O & $\square$ & 地元の小規模保育施設 & 自宅が遠方 \\
\hline
\end{tabular}

注）症例 1 , 症例 5 は他院で診断され, 指導を受けていた症例である。当科で人工内耳埋め込み術を受け, 当科での指導が開始された。

注）症例 7 , 症例 8 は調査時が 3 歳に達していなかったため, 2 歳までの状況を記した。 
は，自宅から特別支援学校が遠く，通うことが困難 という理由があった。しかし， 3 歳以降は居住する 市のことばの教室で受け入れがあり，ことばの教室 で指導を受けることになった。また，症例 $1 ， 5$ は 他院で診断後, 指導も受けていたが，当科で人工内 耳埋め达及術を受け, その後は 2 か所の医療機関で 指導を受けることになった。

このように，重複する障害のない症例では，17名 中 15 名の児が 2 歳または 3 歳までに複数の施設で指 導を受けていた。しかし, 症例 2,15 の 2 名は, 3 歳になっても当科以外の施設には通っていなかっ た。その理由は,「保護者の就労」(症例 2 ),「母親 の出産」（症例15）という家庭の事情であった。

次に，3歳以降の主たる集団保育の場について調 べた結果は， 8 名が特別支援学校の幼稚部， 7 名が 地元の幼稚園または保育所・保育施設であった。

2）重複障害がある症例

重複障害がある 8 例の療育状況を表 5 に示した。 0 歳から 3 歳までに当科と特別支援学校の 2 か所で 指導を受けた児は, 症例 4 と症例 9 の 2 名であっ た。他の 6 名の難聴に関わる指導は当科だけであっ
た。しかし，この 6 名の当科受診の頻度は月 1 回〜 2 か月に 1 回程度と少なかった。診療録を見ると， 難聴の経過観察と補聴器装用及び聴能の発達に関わ る保護者への指導が主な内容であった。全例が 3 歳 までに運動機能または発達全般を促すための指導を 受けており，3歳以降も5名が発達支援を目的に地 域の障害児施設に通っていたが，当科と障害児施設 との連携が行われていなかったため，览の難聴や補 聴器の装用について, 施設側への情報提供がなされ ていなかった。

\section{考察}

当科は，難聴乳幼児の療育について特別支援学校 と連携して行うことを基本にしてきた。しかし，自 宅が遠方，その他，家庭の事情により，特別支援学 校には通わない児を認めた。また，重複障害児は当 科への受診が少なく，発達支援のために通っている 障害児施設との連携が行われていないという問題点 が明らかになった。これらの現状を踏まえ，今後の 山口県に打ける難聴乳幼児の療育を充実させるため の課題について考察を加えた。

表 5 重複障害がある 8 例の療育状況

\begin{tabular}{|c|c|c|c|c|c|c|c|c|c|c|}
\hline \multirow[t]{2}{*}{ 症例 } & \multirow{2}{*}{$\begin{array}{l}\text { 難聴の } \\
\text { 程度 }\end{array}$} & \multirow[t]{2}{*}{ 重複する障害 } & \multirow[t]{2}{*}{ 特記事項 } & \multicolumn{4}{|c|}{$\begin{array}{c}\text { 難聴に関わる指導を } \\
\text { 受けた施設 }\end{array}$} & \multirow{2}{*}{$\begin{array}{l}\text { 当科受診 } \\
\text { の頻度 }\end{array}$} & \multirow{2}{*}{$\begin{array}{c}3 \text { 歳までに受けた } \\
\text { 難聴以外の指導 }\end{array}$} & \multirow{2}{*}{$\begin{array}{l}3 \text { 歳以降の主たる } \\
\text { 集団保育の場 }\end{array}$} \\
\hline & & & & 0 歳 & 1 歳 & 2 歳 & 3 歳 & & & \\
\hline 4 & 重度 & $\begin{array}{c}\text { 自閉症スペクトラム, } \\
\text { 精神発達荤滞 }\end{array}$ & & 미 & On & 미 & On & 月 1 回 & 有 ( 1 か所 : 発達全般) & $\begin{array}{l}\text { 児童発達支援センター, } \\
\text { 特別支援学校幼稚部 }\end{array}$ \\
\hline 9 & \multirow{7}{*}{ 中等度 } & 精神・運動発達遲滞 & $\begin{array}{l}\text { 先天性サイトメガロウ } \\
\text { イルス感染症 }\end{array}$ & $\bullet$ & 무 & 미 & On & $\begin{array}{r}\text { 月 } 1 \text { 回 } \\
\text { 月 } 2 \text { 回 }\end{array}$ & 有 ( 1 か所：運動機能) & 地元の幼稚園 \\
\hline 10 & & $\begin{array}{l}\text { 脳性麻痷, } \\
\text { 精神発達遅滞 }\end{array}$ & $\begin{array}{l}\text { 先天性サイトメガロウ } \\
\text { イルス感染症 } \\
\text { 小児喘息, 喉頭軟化症, } \\
\text { 揑食・嶼下障害 }\end{array}$ & 0 & 0 & 0 & $\bullet$ & 月 1 回 & 有 ( 1 か所 : 発達全般) & - \\
\hline 11 & & 精神 - 運動発達遅滞 & ダウン症 & ○ & $\bullet$ & $\bullet$ & $\bullet$ & 月 1 回 & 有 ( 1 か所: 発達全般) & 児童発達支援センター \\
\hline 19 & & 精神 - 運動発達痒滞 & 左外耳道閉鎖， ダウン症 & $\bullet$ & 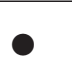 & $\bullet$ & $\bullet$ & $\begin{array}{l}\text { 月 } 1 \text { 回 } \\
2 \text { 加 } 1 \text { 回 }\end{array}$ & 有 ( 1 か所: 発達全般) & 障害児の通所施設 \\
\hline 20 & & 精神・運動発達遅滞 & $\begin{array}{l}\text { 超低出生体重児, 仮死, } \\
\text { 人工換気 }\end{array}$ & ○ & 0 & $\bullet$ & $\bullet$ & $\begin{array}{l}\text { 月 } 1 \text { 回 } \\
2 \text { 加 } 1 \text { 回 }\end{array}$ & 有 ( 1 か所: 発達全般) & 地元の保育所 \\
\hline 21 & & 精神・運動発達遅滞 & $\begin{array}{l}\text { 高ビリルビン血症, } \\
\text { 先天性水頭症 }\end{array}$ & 0 & 0 & ○ & $\bullet$ & 月 1 回 & $\begin{array}{r}\text { 有 (1 か所：運動機能 }) \\
(2 \text { 所：発達全般 })\end{array}$ & 障害児の通所施設 \\
\hline 23 & & $\begin{array}{l}\text { 脳性麻㾝, } \\
\text { 精神発達遅滞 }\end{array}$ & ピエール・ロバン症候群 & $\bullet$ & 0 & $\bullet$ & $\bullet$ & $\begin{array}{l}\text { 月 } 1 \text { 回 } \\
2 \text { 加 } 1 \text { 回 }\end{array}$ & 有 ( 1 か所: 発達全般) & 障害児の通所施設 \\
\hline
\end{tabular}

注）症例 4 は, 児童発達支援センターと特別支援学校の併行利用。

注）症例10は, 健康管理上の理由で，集団保育は受けていない。 
1. 身近な地域で難聴児を受け入れる体制の充実 早期に難聴が発見され，その後，就学前まで長期 に渡って療育を受けるためには，児と保護者が通い やすい近くの場所に施設があることが重要である。 今後は，地域で難聴児を受け入れる施設を拡充する 必要がある。具体的な対策としては，地域の児童発 達支援センターを活用することが考えられる。児童 発達支援センターは，平成 24 年 4 月に改正された児 童福祉法によって創設され，障害の種別に関係な く，地域の障害のある児に対する支援を行う役割を 担っている。山口県の場合, 障害福祉圈域ごとに設 置された児童発達支援センターが 5 か所ある ${ }^{5)}$ が, 現在，難聴児のクラスを設置している施設は東部の 1 か所だけである。今後，他の 4 か所にも同様に難 聴児のクラスが設置され，身近な地域で支援が受け られる体制の充実を図ることが大切である。ただ し，児童発達支援センターに難聴児を受け入れる場 合，言語聴覚士の確保や聴力検査室の設置の問題を 考える必要がある。主として難聴児を通わせる児童 発達支援センターでは言語聴覚士や聴力検查室が必 須とされるが，知的障害のある览が主として通う施 設では必須ではない。山口県の場合, 知的障害のあ る児が主として通うほぼすべての児童発達支援セン ターに言語聴覚士がいる。そこで, 聴覚検査は医療 機関が担い，療育は児童発達支援センターで行うと いう体制を整えれば，難聴児の支援が身近な地域で も可能になると考えられる。

\section{2. 家庭訪問による指導}

今回の対象児の中に，生後 6 か月まで精査機関を 訪れず，その後も受診が途絶えがちで, 補聴器装用 開始が遅れた児を認めた。山口県の新生児聴覚検査 事業では，要精査となった児の支援を行うシステム が構築されており，保健師が家庭訪問を行ってい $る^{(123)}$ 。しかし，森田ら ${ }^{6)}$ が報告しているように， 要精查となった児の保護者は精神的負担を抱えてい たため，精査機関を訪れるまでに期間を要したので はないかと考えられた。また，診断から間もない時 期には，児の難聴を認め難く，補聴器の受け容れに 抵抗を感じる保護者の心情も考えられる4)。このよ うな保護者に対し，心理面のサポートをしつつ，難 聴児の発達に必要な支援を早期から開始できるよ う，家庭訪問には言語聴覚士が同行することが望ま
しいと考える。廣田 ${ }^{7}$ は，新生児聴覚検査後に医師 や保健師に言語聴覚士や特別支援教育の教師も加わ り，診断から療育，教育へと支援の流れが円滑に行 われることが重要と述べている。また，中村8) も， 難聴の疑義および診断直後から家族に必要な介入を し，早期から保護者支援を行うことの大切さを唱え ている。山口県では，聴覚障害児に関わる医療，教 育，福祉の関係者が一堂に会する場が年に 1 回，設 けられている。その際, 新生児聴覚スクリーニング の実施率や精査機関，療育機関，教育機関について の最新の情報が提供される。今後は，精査に至る段 階から療育開始後までの現状と問題点を定期的に協 議することが大切である。なぜなら，協議を行うこ とで児と保護者に必要な支援を見出すことができる からである。精査や聴覚管理に関わる耳鼻咽喉科医 や言語聴覚士は，幼い時期から長期間，難聴児に関 わるため, 児の成長の姿を把握しやすい。今後は, 耳鼻咽喉科医や言語聴覚士から保育者や教員に働き かけ，児の発達に一貫して行う支援について，共通 理解を深めることが重要である。

0 歳から 3 歳頃までの低年齢のうちは家庭で過ご す時間が大半を占めるため, 療育も家庭を中心に行 うことが自然であると考えられる。言語聴覚士は家 庭療育を支援する立場で，家庭での過ごし方や子ど もへの関わり方を保護者にわかりやすく伝える必要 がある。中村 ${ }^{8)}$ が 0 歳児の療育の目的を，安定した 母子コミュニケーションを保障し, 必要な養育環境 を整え，健やかな母子関係を育むことと述べている ように，早期療育における言語聴覚士の役割は，親 子の基本的なコミュニケーションの形成を支援する ことである。そして，その支援は日常生活を通して 行うことが大切であると考えられる。それには，家 庭訪問が親子の自然な姿が見られ，適切な方法であ ると考えられる。しかし，家庭訪問を実施するには 時間と人材が必要である。山口県の場合，障害児療 育等支援事業を行っている览童発達支援センターの スタッフが家庭に出向き, 相談や療育指導を行うこ とができるので，この事業を活用し，訪問による指 導をすすめていくことが現実的と考える。

3。重複障害児が通っている障害児施設との連携 重複障害児には，当科への受診が月 1 回〜 2 か月 に1 回程度の児を複数認めた。いずれも早期から運 
動訓練や発達全般の指導に関わる専門機関にも通 い, 出かけることが多い生活であったと考えられ る。それが難聴に関わる指導を受ける回数に影響を 及ぼしたのではないかと考えられた。その場合に は，児の療育先である障害児施設と連携し，施設で の一日を通して, 聴能の発達を促すための取り組み が行われる必要があると考えられる。今後は, 施設 の担当者に児の難聴や補聴器装用についての情報提 供を行う必要がある。また，施設の中で児のきこえ の環境が整備されるよう，医師や言語聴覚士が訪問 し，担当者に直接，説明を行うことが望ましいと考 える。北川ら ${ }^{9)}$ も同様に, 子どもが快適に補聴器を 使えるように環境を整え, 地元の通園スタッフとも 連携すると述べている。今後は, 当科と各施設との 間で情報交換を行い，発達全般に関わる支援を行う 際に難聴への配慮がなされるよう, 療育内容を共に 検討する機会が必要であると考えられる。

本論文の要旨は, 第59回日本聴覚医学会総会・学 術講演会（2014年，下関市）で口演した。

\section{Problems related to treatment and educa- tion provided for infants with hearing loss living in Yamaguchi Prefecture}

\author{
Aiko Nakatsu, ${ }^{1,2)}$, Makoto Hashimoto ${ }^{1,2)}$, Kazuma \\ Sugahara $^{1)}$, Hiroaki Shimogori ${ }^{1)}$, Takuo Ikeda ${ }^{3)}$, \\ Hiroshi Yamashita, ${ }^{1,2)}$ \\ ${ }^{1)}$ Department of Otolaryngology, Graduate \\ school of Medicine, University of Yamaguchi \\ ${ }^{2)}$ Center for High Integrated Sensations, Yama- \\ guchi University Hospital \\ ${ }^{3)}$ Otolaryngology, Tsuzumigaura Handicapped \\ Childrens' Hospital
}

The present study was conducted to identify and discuss the problems related to treatment and education provided for infants with hearing loss living in Yamaguchi Prefecture, in order to improve the system. The subjects were 25 infants whose parents had consulted the Department of Otorhino- laryngology of Yamaguchi University Hospital between June 1998 and December 2012 and fulfilled the following conduction criteria: hearing loss was identified when they were under 1 year old, and information on the courses of treatment and education was available.

A review of the medical records was conducted to determine the original reasons for suspecting hearing loss and conducting the hearing tests at the age at which the infant underwent a thorough examination for the first time, the age at which the infant started using a hearing aid, and the period of treatment and education for the heaing loss.

As one of the problems identified in relation to the provision of treatment and education, since the number of institutions that provide children with these services is limited, there were infants who were unable to receive these services unless they attended institutions far from their homes.

In the future, it will be necessary to improve the system to implement treatment and education at the community level.

\section{参考文献}

1) 山下裕司：聴覚に関わる社会医学的諸問題「新 生児聴覚スクリーニングの現状と課題」. Audiology Japan 55 : 111-117, 2012

2 ）山下裕司, 池田卓生, 三浦正子, 他：山口県に おける新生児聴覚スクリーニングとそのフォロー アップ体制について. Audiology Japan 46: 535536, 2003

3 ）山口県健康福祉部増進課：山口県母子保健ガイ ド＼cjkstart新生児聴覚検査ハンドブック． 2014

4 ）中津愛子, 橋本 誠, 菅原一真, 他：難聴児の 療育と支援に関わる問題点の検討. Audiology Japan 56: 735-742, 2013

5 ）岡本 実: 施設・専門機関の地域ネットワー ク. 水田和江, 増田貴人編, 新障害のある子ども の保育実践, 158-159, 学文社, 東京, 2014

6 ）森田訓子, 伊藤茂彦, 山口 暁 : 新生児聴覚又 クリーニングの問題点と今後の課題一保護者への アンケート調査による検討一. Audiology Japan 
47: 49-55, 2004

7 ）廣田栄子：乳幼児難聴の聴覚医学的問題「早期 診断と早期療育の問題点」. Audiology Japan 56 : 199-211, 2013

8 ）中村公枝：聴覚障害乳児の早期療育。音声言語 医学 45：217-223，2004

9 ）北川可恵, 光澤博昭, 新谷朋子, 他：当セン夕 一母子入院における重複障害児の補聴器装用指 導. Audiology Japan 56 : 171-177, 2013

(2015年2月3日受稿 2015年3月9日受理)
別冊請求先 : $\bar{\top} 755-8505$

山口県宇部市南小串1-1-1

山口大学大学院医学系研究科耳鼻咽喉 科学分野

中津愛子

Aiko Nakatsu

Department of Otolaryngology, Graduate school of Medicine, University of Yamaguchi,

1-1-1 Minamikogushi, Ube, Yamaguchi 755-8505, Japan 